Daniel Dujava $^{1}$

Institute of Economic Research,
Slovak Academy of Sciences

SCIENTIFIC REVIEW ARTICLE

doi:10.5937/ekonomika1504079D

Ján Dráb ${ }^{2}$

Faculty of Commerce,

University of Economics in Bratislava

Received: October 13, 2015

Accepted: November 16, 2015

\title{
HOW DIFFERENT MONETARY RULES LEAD TO DIFFERENT PERFORMANCES DURING THE CRISES: THE CASE OF THE WESTERN BALKAN COUNTRIES ${ }^{3}$
}

\begin{abstract}
The Great Recession reopened macroeconomic issues that had been previously considered as solved. One of them is the use of monetary and fiscal policy to stabilize macroeconomic development. Although the prevailing consensus used to be that monetary policy is powerful enough to ensure smooth economic performance, the Great Recession produced the need for fiscal stimulus in many countries. This paper analyses the impact of a different policy-mix with emphasis on different monetary policy rules in the Western Balkan countries. Using data of the main macroeconomic indicators, the authors demonstrate that the monetary policy regime still remains a key determinant of economic performance during the economic crisis.
\end{abstract}

Key words: monetary policy, the great recession, Western Balkan countries, Mundell Fleming model, international trade.

JEL classification: E32, E52, E63

\section{КАКО РАЗЛИЧИТА МОНЕТАРНА ПРАВИЛА ВОДЕ ДО РАЗЛИЧИТЕ ЕФИКАСНОСТИ ПРИВРЕДЕ: СЛУЧАЈ ЗЕМАЉА ЗАПАДНОГ БАЛКАНА}

\begin{abstract}
Апстракт
Велика рецесија поново отвора макроекономска питања која су се раније сматрала решеним. Једно од юих је употреба монетарне и фискалне политике у стабилизацији макроекономског развоја. Иако некада преовладава консензус монетарна политика је довољно снажана да се осигура несметан

\footnotetext{
${ }^{1}$ duniel.dujava@savba.com

2 jan.drab23@gmail.com

${ }^{3}$ This work was supported by a research project of the Ministry of Education, Family and Sports of the Slovak Republic VEGA (in the period 2014 - 2016). No. 1/0550/14: "New Challenges In European Energy Security And Their Impact on the EU Competitiveness in Horizon by 2020." and also by the research project of the Ministry of Education, Family and Sports of the Slovak Republic VEGA (in the period 2015 - 2018). No. 2/0070/15: "The Dynamics and Nature of Changes in the Slovak Economy in the Phase of Expected Stabilisation of Economic Growth. We would like to thank Menbere Workie Tiruneh and Lenka Drobcová for their comments and insights.
} 
економски учинак, Велике Рецесије и потребе за фискалним стимулансом у многим земљама. Овај рад анализира утицај различитих политика мешања са нагласком на различита правила монетарне политике у земљама Западног Балкана. Користећи податке са главних макроекономских показатеља ми смо показали да је режим монетарне политике и даље остаје кључна одредница економских перформанси током економске кризе.

Кључне речи: монетарна политика, Велике рецесије, земље западног Балкана, Мандел-Флеминг модел, међународна трговина.

\section{Introduction}

Financial and economic crisis of 2007-2008, so called the Great Recession, had a crucial impact on the business environment. The rate of economic growth of the Western Balkan countries suddenly decreased and it has become unclear, whether it is possible to sustain pre-crisis growth rates. The Great Recession has also reopened several macroeconomic issues which had been considered as settled for the time being. The use of monetary and fiscal policy as a stabilization tool and the elementary setting for sustainable business environment is one of them.

Prevailing pre-crisis consensus was that economic fluctuations can be eliminated by stabilization of aggregate demand. Most economists believed that this could be achieved by using monetary policy alone. In macroeconomics, there are several arguments to support this hypothesis. One of the plausible arguments is linked to the fact that monetary policy is considered to be less distortionary than fiscal policy. In addition, in an economy using fiat money, nothing limits monetary policy in boosting the aggregate demand. Monetary policy has become a preferred stabilization tool in accordance with the well known rule stating that one policy instrument should be used to achieve one policy goal.

Government budget has become viewed as an instrument of supply-side policy.

These views survived even Japan's lost decade (lasting much more than ten years), when the Bank of Japan failed to prevent deflation. However, the Great Recession forced economists to reconsider these views. Once interest rates hit zero lower bound, the central banks of many developed countries lost control over the aggregate demand and it became clear that the role of monetary and fiscal policy is not as clear-cut as we had thought. However, recently reopened discussions about stabilization policy focus mainly on large economies experiencing relatively modest flows of goods and services, for example the US, the Euro Area and Japan. These issues are much more complicated in small open economies.

Western Balkan countries provide a unique opportunity to study the advantages and disadvantages of different monetary regimes. We focus on Albania, Serbia, Montenegro, Macedonia and Bosnia and Herzegovina (we exclude Kosovo due to missing data and Croatia because of its much higher GDP per capita but also due its full membership with the EU since 2014). These countries share similar history, culture, economic characteristics, structure of foreign trade and were hit by a similar shock. On the other hand, different monetary regimes are used there. Albania and Serbia follow inflation targeting monetary policy (Albania being much more successful), Macedonia pegs the exchange rate to the euro, Bosnia and Herzegovina uses the currency board (backing its currency by the euro) and Montenegro uses the euro instead of its own currency.

From deep recession in Montenegro to one of the few growing countries in Europe, Albania, a relatively similar economic development in the pre-crisis period turned to a 
completely different situation. We argue that (1) the monetary regime proved to be an important determinant of economic performance (2), but the fiscal policy (especially tax cuts) is not to be underestimated. These two instruments were capable of guaranteeing a sufficient demand and thus help to provide a good environment for entrepreneurship in the Western Balkans. Furthermore, (3) the way the monetary regime determined the reaction of an economy to shocks is in line with well-known textbook Mundell-Fleming model.

Next section offers a literature review. Part two describes the nature of shocks which hit the Western Balkan countries and provides a theoretical prediction of their impact on an economy conditional on monetary regime. Part three confronts theoretical predictions of the Mundell-Fleming model with actual development in individual countries. The last section offers the conclusion.

\section{Literature review}

If a small open economy decides to stabilize output and inflation using monetary policy, it has to be willing either to tolerate fluctuations of exchange rates or to control the capital flows. A volatile exchange rate can be a source of additional costs. Capital control closes the economy to a certain degree. Therefore, arguments in favour of monetary policy are somehow weaker. Nevertheless, most authors comparing flexible and fixed regimes conclude that the floating exchange rates are preferable even in a small open economy. Krugman, et. al. consider the autonomy of the monetary policy (better ability to control money supply) to be an important advantage of floating exchange rates. Furthermore, the exchange rate operates as an automatic stabilizer. (Krugman, et. al., 2014, Mankiw, 2009)

These two properties of floating exchange rates are well described by the MundellFleming model (Fleming, 1962; Mundell 1963). Let us summarize the main results of this well-known model focusing on the effects of the downward shift in exports, since this case is the most relevant for our analysis.

Lower exports, caused for example by recession in export markets, cause downward pressures on exchange rates - domestic currency tends to depreciate.

Under the flexible exchange rates (used by Albania and Serbia), exchange rate depreciation increases the volume of exports and gives incentive to households and firms to substitute imported goods by domestic production. As a result, the net exports rise partly offsetting the effect of the slowdown of trading partners' economies. Furthermore, if the central bank targets inflation, it should be willing to do a monetary expansion to stimulate demand even if it leads to even weaker currency. Overall expected effect is a modest decrease in real activity and a significant currency depreciation.

If a country fixes the exchange rate (like Macedonia does), the central bank cannot allow the currency to depreciate. To combat the downward pressures on the exchange rate, it has to use monetary restriction or at least it has to be less expansionary. This has two negative effects on output: (1) since the currency does not depreciate, the net exports do not rise (ceteris paribus) and (2) the aggregate demand is further weakened by the monetary restriction. The country keeps the exchange rate fixed at the cost of deep recession.

Very similar effects are to be expected in a country using the currency board (for instance in Bosnia and Herzegovina) and in a country without its own currency (Montenegro). Both lower external demand for goods and services and lower capital 
inflows lead to a negative balance of payments. Instead of monetary restriction of the central bank, the money stock shrinks because of balance-of-payments mechanism.

In most cases, once the central bank chooses not to target the exchange rate, the rate of inflation is selected as the monetary-policy target. Therefore, most studies deal with the issue of optimal monetary regime comparing the exchange rate targeting to the inflation targeting.

Monacelli and Galí point out the trade-off between the stabilization of domestic inflation and the output gap on the one hand and the stabilization of the nominal exchange rate and the terms of trade on the other hand. They conclude that the optimal volatility of exchange rate is proportional to the openness of the economy (Galí, et. al., 2005).

Batini, et. al. (2009) argue that inflation targeting is superior to the stabilization of exchange rate and that the financially unstable emerging-market economies should "fear to fix" rather than "fear to float". They support their findings with the analysis of Chilean monetary policy.

Dennis (2001) reaches the same conclusion, but he considers the exchange rate movements to be a source of valuable information even under inflation targeting. Taking the exchange rate into consideration in the monetary-policy decisions can lead to better economic outcomes. Clarida, et al. (2001) argue that the optimal monetary policy in an open economy does not differ from the optimal monetary policy in a closed economy. Lama, et. al. (2007) show that the central bank in a small open economy should stabilize the inflation of non-tradeable goods. Gyu Choi, et. al. (2003) show in a model with habit formation that the monetary policy in a small open economy should take into the account the world interest rate. Kolasa, et. al. (2011) build a more complicated model and argue that the monetary policy should also take into the account the balance-sheets shocks and the foreign debt.

It is necessary to understand that different monetary regimes might perform differently under different shocks. Parrado (2004) compares the inflation targeting and the exchange rate rules. He states that under external and real shocks, the social costs are significantly higher when the exchange rate is managed. On the other hand, in the case of nominal shocks, the loss is higher when a flexible exchange rate is applied. De Paoli (2004) also concludes that the reactions of policy makers should differ according to the source of negative shock. Faia, et. al. (2008) show that home bias in consumption makes it desirable to stabilize the exchange rate to a certain degree.

Most advanced countries using flexible exchange rates choose the rate of inflation as a target of their monetary policy. However, this is not the only choice. According to Merola (2010), a price level targeting policy produces lower levels of volatility of interest rates and exchange rates. Price level targeting policy reduces the risk of deflation and affects the private sector's expectations in such a way that they work as automatic stabilizers.

Despite these arguments in favour of flexible exchange rates, many countries choose to keep the exchange rates fixed. What is the rationale behind? According to Krugman, et. al. a fixed exchange rate works as a guarantee for exporters and importers and foreign investors that no unexpected appreciations or depreciations will occur.

Conduct of monetary policy is even much more complicated in countries with populist governments and in the countries with serious threats of populist parties gaining power. In these cases, "money printing" can be easily used not as a stabilization tool, but as means to raise revenues. High inflation becomes a permanent threat and it is not unthinkable that high inflation will turn into hyperinflation, which usually goes hand in hand with additional political risks (risk of expropriation, for instance). Therefore, a government can choose to peg its currency for example to dollar or euro (or recently mark) 
or to adopt a currency board when every single unit of domestic currency is backed by foreign currency. Even more extreme case is giving up own currency altogether, so called dollarization. These measures mean giving up the monetary policy, but it provides a guarantee to foreign inventors that a government will "behave responsibly". A significant number of developing countries have to weigh the advantages of guaranteeing financial stability against the disadvantages of giving up the most powerful tool of macroeconomic stabilization.

\section{Results and discussion}

\subsection{Nature of shocks and expected macroeconomic effects}

What exactly was the nature of shocks that hit Balkan countries during the crisis?

First of all, we must emphasise that since the economic crisis did not originate in the Balkans, all shocks were external. The most important one was the decline in exports caused by the economic slowdown of the region's trading partners. Secondly, the global economic crisis led to decline of domestic investment demand with similar effects. Thirdly, Western Balkan countries have experienced a decrease of capital inflows. Table 1 shows annual growth rates of exports and investments in current prices (we choose current prices instead of constant prices because aggregate demand, i.e. nominal GDP, is expressed in current prices) and capital inflows expressed as a percentage of the GDP two years before the crises and two years during the crisis.

All these shocks are negative demand shocks. Decreases in external demand and in capital inflows also create downward pressures on domestic currency.

Furthermore, a weaker economy decreases the money demand and pushes interest rates down. This makes the country less attractive for foreign investors, which could create even more pressures on currency depreciation. However, since the world interest rates also decreased, this effect is probably not very significant.

Table 1. Shocks experienced by Western Balkan countries

\begin{tabular}{lcccccc}
\hline & $\begin{array}{c}\text { ANNUAL GROWTH } \\
\text { RATE OF EXPORTS } \\
\text { (CURRENT PRICES) }\end{array}$ & $\begin{array}{c}\text { ANNUAL GROWTH } \\
\text { RATE OF INVESTMENT } \\
\text { (CURRENT PRICES) }\end{array}$ & \multicolumn{2}{c}{$\begin{array}{c}\text { AVERAGE CAPITAL } \\
\text { INFLOW }\end{array}$} \\
\hline (PERCENT OF GDP)
\end{tabular}

Source: World Development Indicators of The World Bank

In general, all the countries are economies with weaker external and domestic demand and downward pressures on the exchange rate. According to Mundell-Fleming model, actual reaction of an economy on such shocks depends on the reaction of the central bank, i.e. on the monetary policy. Monetary policy is in turn determined by the monetary regime. 


\subsection{Policy mix and its impact on economic performance in individual countries}

\subsubsection{Monetary Policy}

To assess how expansionary or how restrictive monetary policy in a particular country was, we focused on two indicators: (1) the interest rates and (2) the monetary base. In case of Montenegro which uses the euro, data for monetary base are not available. Therefore, we decided to use the monetary aggregate M1 instead. Furthermore, since Montenegro does not have its own currency, we do not report its interest rates.

In 2009 - the moment the crisis hit Western Balkans - only the central banks targeting inflation decided to cut the interest rates. In Albania, the central bank decreased basic rate from $6.3 \%$ to $5.7 \%$, much more inflationary Serbia experienced a drop from $12.4 \%$ to $10.8 \%$. Monetary base in Serbia and Albania stayed on their pre-crisis trend (increasing about $10 \%$ per year).

Figure 1. Interest rates

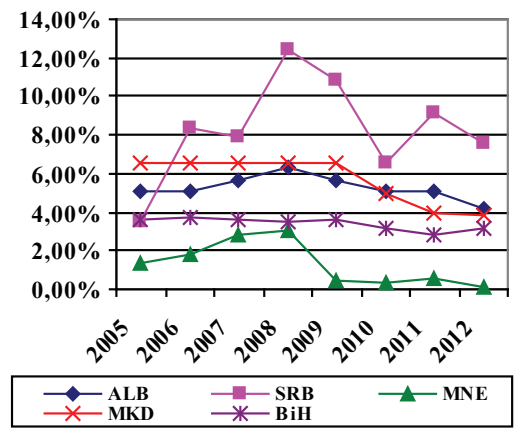

Source: Central banks of respective
Figure 2. Monetary base

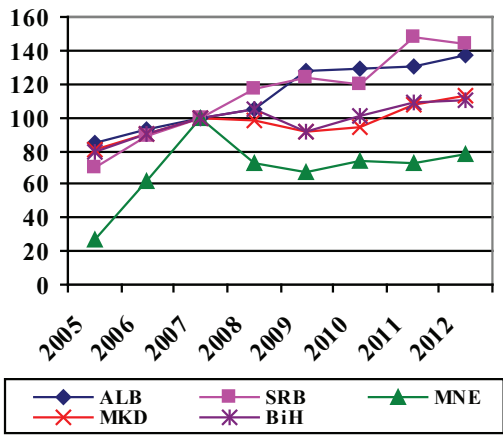

Source: Central banks of respective countries

On the other hand, Macedonia and Bosnia and Herzegovina kept the interest rates unchanged to protect their currencies. Their monetary base in 2009 was about $10 \%$ smaller than in 2007.

There was even more radical restriction in money stock in Monetenegro, where M1 had shrunk to only two thirds of its pre-crisis level. The difference between the money supply in Montenegro and other countries is even more pronounced if the monetary aggregate M2 is considered. Whereas in Albania, Serbia and even Bosnia, M2 was higher in 2009 than in 2007 and in Macedonia only 5\% decrease was observed, Montenegro experienced the decrease of $20 \%$ !

Monetary restriction prevents currency depreciation using two channels:

(1) In the long run, a smaller supply of domestic currency decreases the price level. It follows from purchasing power parity theory that currency appreciates.

(2) However, in the short run, fluctuations in the exchange rate are mostly governed by the capital markets. Monetary restriction increases the interest rates which makes a country more attractive for foreign investors. 
Furthermore, if markets believe that the central bank will fight against downward pressures on the exchange rate, the expected return on capital is higher. To understand why, it is important to note that the return on capital equals the interest rate plus expected appreciation of the domestic currency. Under the floating exchange rates, the exchange rate is expected to depreciate, under the fixed exchange rates, the central bank is expected to keep the peg.

We conclude that monetary policies in Western Balkan countries follow predictions of the Mundell-Fleming model. Monetary policy in the inflation-targeting countries were indeed much more expansionary than in the countries fixing the exchange rate. Taking into consideration changes in the exchange rates, ex post return on capital (interest rate + domestic currency appreciation) in Albania (about -6\%) and Serbia (about -10\%), were significantly lower than in Macedonia (about $0 \%$ ) and Bosnia (about $-1.5 \%$ ). Montenegro as a country without its own currency experienced a sharp decrease in money stock which had a restrictive effect on the economy.

Let us briefly discuss the main channels of monetary transmission in the Western Balkans in more detail. Expansionary monetary policy leads to a depreciation of the exchange rate and thus boosts exports, but not necessarily in those trading partners which were hit by the crisis. In other words, the monetary expansion should not only increase the volume of exports, but also change the structure of international trade.

Figure 3 shows the share of exports in the euro area and in countries which peg their currencies to the euro. In Albania and Serbia - countries with a flexible exchange rate regime and expansionary monetary policy, we observe a temporary drop in the share of countries using the euro on their exports. On the other hand, no such thing is observed in Bosnia and Macedonia. However, in this respect, Montenegro behaves more like a country with flexible exchange rate. This will be the subject of a further research.

Figure 3. Share of countries using the euro and pegging their currencies to the euro on exports

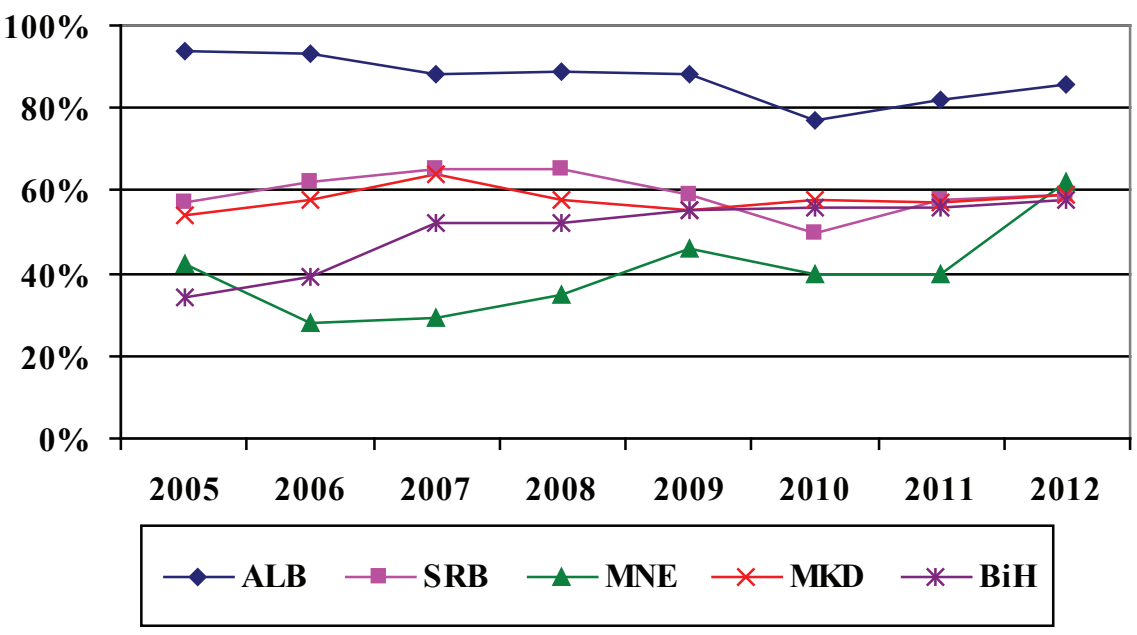

Source: Statistical offices of Albania, Serbia and Montenegro, Central Banks of Macedonia and Bosnia and Herzegovina 


\subsubsection{Fiscal Policy}

How did the fiscal policy react in the face of the crisis? We have mentioned that once the central bank targets inflation, the fiscal policy is unnecessary. However, the countries fixing the exchange rate might find the fiscal policy useful.

Growth rates of government expenditures before the crisis and during the crisis confirm that neither Albania nor Serbia engaged themselves in a massive fiscal expansion. On the contrary, during the crisis, government expenditures grew much more slowly. On the other hand, Albanian deficit increased as the results of a cut in the corporate and personal income tax rates from $20 \%$ to $10 \%$ which took effect in 2008 . Therefore, the Albanian fiscal policy can be considered as slightly expansionary, albeit not as much as the fiscal policy in countries with the fixed exchange rates since Montenegro, Macedonia and Bosnia and Herzegovina experienced an increase in growth rates of government expenditures. Serbia remains the country with the most restrictive fiscal policy. It is also important to mention that the fiscal expansion in Montenegro, Macedonia and Bosnia and Herzegovina was done mostly by increasing government expenditures. However, Macedonia also cut the corporate and personal income taxes, but this was done before the crises.

Figure 4. Average growth rates of government expenditures
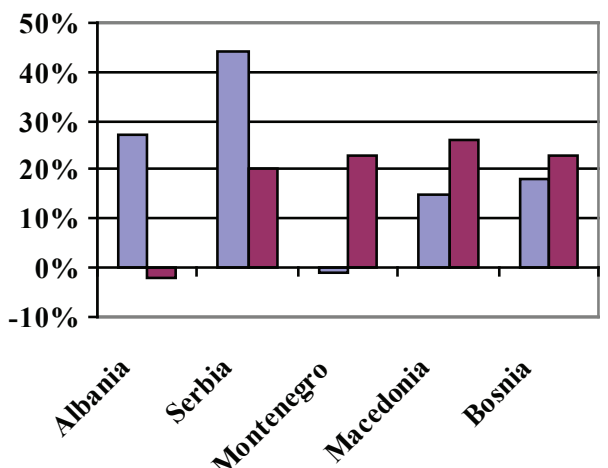

$\square * 06-08 \square * 08-10$

Source: $\quad$ World Development Indicators of The World Bank
Figure 5. Average government balance (\%GDP)

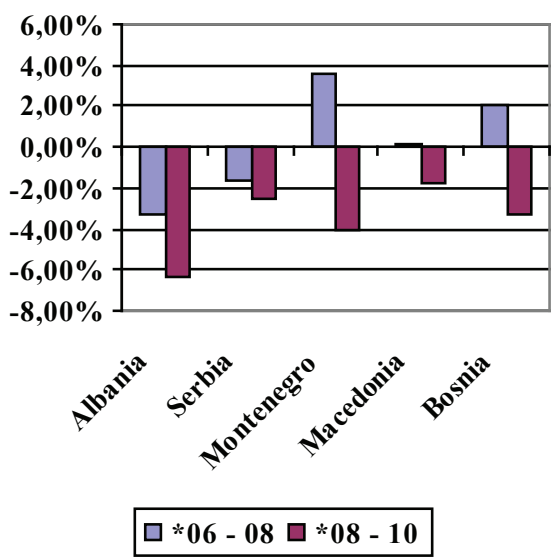

Source: Source: tradingeconomics.com

\subsection{Impact of policy mix on economic performance}

We have documented significant differences in the policy mix in the Western Balkan countries. Differences in policy were reflected in a different performance. What outcomes are to be expected?

It is natural to expect Albania being the best performing country. This country is relatively successful in targeting inflation. Furthermore, tax cuts might improve economic performance through supply-side channel even if they were not strictly necessary as a stabilization tool. 
Serbia also targets inflation, but it is much less successful. In 2005, inflation was $17 \%$, a year later $6,6 \%$, in 2007 inflation rate returned to double-digit values $(11 \%)$. In the environment of historically unstable inflation (and consequently unstable inflation expectations), the monetary policy is hardly powerful enough to stabilize the economy. Furthermore, it is also not certain that the central bank will offset the fiscal restriction by the monetary expansion, which is important, since Serbia has the most restrictive fiscal policy.

Montenegro, Macedonia and Bosnia and Herzegovina fix the exchange rate, but they engaged in fiscal expansion. How successful the fiscal policy is in supplementing the monetary policy depends on particular circumstances.

Figures 6 and 7 show the rates of economic growth and unemployment in different countries before and during the crises.

Figure 6. Economic growth

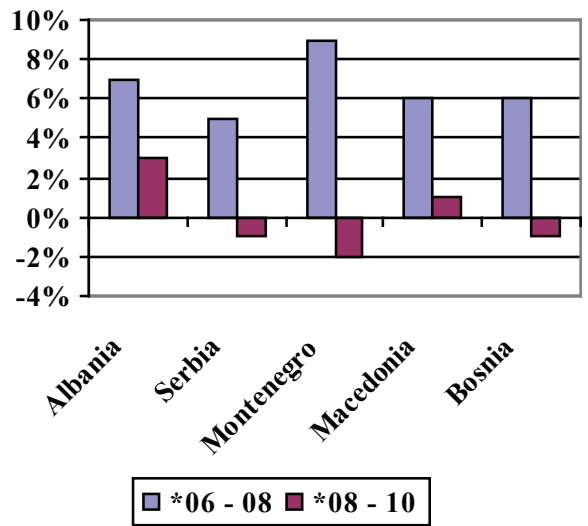

Source: World Development Indicators of The World Bank
Figure 7. Unemployment

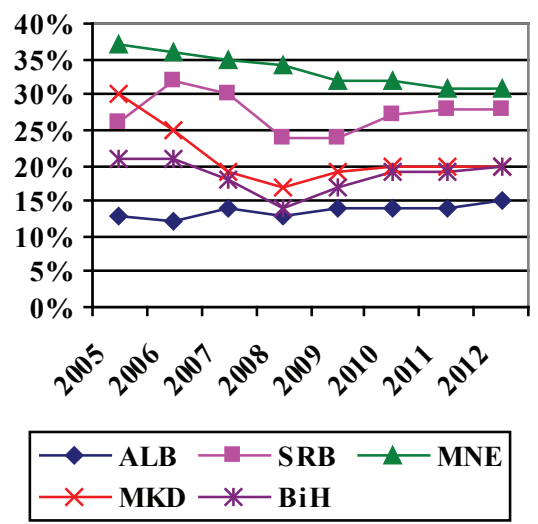

Source: World Development Indicators of The World Bank

Taking these two indicators into account, it is evident that Albania was indeed the most successful economy. The drop in growth rate was not so significant and the unemployment rate did not rise.

The second best performing economy is Macedonia, despite the fixed exchange rate. This country engaged in fiscal policy and the tax cuts similar to Albania.

Although Serbia targets inflation, it managed only to postpone the increase of unemployment for one year, the real economic activity slowed down significantly. All in all, Serbia did not perform better than Bosnia and Herzegovina using the currency board.

Montenegro using the foreign currency is the worst performer. Starting with the unemployment exceeding $35 \%$, it has not experienced any rise in the unemployment rate, but the economy, which managed to grow by $9 \%$ before the crisis experienced a negative growth. This is undoubtedly an economic disaster.

\section{Conclusion}

Western Balkan countries provide an evidence that the floating exchange rate together with responsible inflation targeting might be the best combination if the economic stabilization is a policy goal. This is the case of Albania. However, Serbian 
experience proves that the currency depreciation might not avert the crisis if the central bank is unable to stabilize the inflation and doubly so when external shocks are coupled with fiscal restriction. Serbian economic performance is comparable to Bosnia and Herzegovina, where the currency board is used. The Macedonian example shows that the fixed exchange rate and fiscal expansion (namely tax cuts) might be better solutions. From the viewpoint of macroeconomic stabilization, using the foreign currency is probably not the best way to go forward, the drop in the money supply due to the balance-of-payment mechanism has restrictive effect and caused a deep recession in Montenegro.

\section{References}

Batini, N., Levine, P., \& Pearlman, J. (2009). Monetary and Fiscal Rules in an Emerging Small Open Economy. IMF Working Paper, WP/09/22.

Clarida, R., Galí, J., \& Gerlter, M. (2001): Optimal Monetary Policy In Open Versus Closed Economies. American Economic Review, 2001, v. 91 (2, May), 248-252.

De Paoli, B. (2004). Monetary Policy and Welfare in a Small Open Economy. London School of Economics and CEP.

Dennis, R. (2001). Monetary Policy and Exchange Rates in Small Open Economies, FRBSF Economic Letter.

Faia, E., \& Monacelli, T. (2008). Optimal Monetary Policy in a Small Open Economy with Home Bias. Journal of Money, Credit and Banking, 40, 4, 721-750.

Fleming, J. M. (1962). Domestic financial policies under fixed and floating exchange rates. IMF Staff Papers 9, 369-379.

Galí, J., \& Monacelli, T. (2005). Monetary Policy and Exchange Rate Volatility in a Small Open Economy. Review of Economic Studies, 72, 707-734.

Gyu Choi, W., \& Jung, Y. (2003). Optimal Monetary Policy in a Small Open Economy with Habit Formation and Nominal Rigidities. IMF Working paper 03, 05.

Kolasa, M., \& Lombardo, G. (2011). Financial Frictions and Optimal Monetary Policy in an Open Economy. ECB Working Paper Series, No. 1338.

Krugman, P. R., Obstfeld, M., \& Melitz, M. (2014). International Economics: Theory \& Policy. Harlow, UK: Tenth Edition Pearson Education Limited.

Lama, R., \& Medina, J. P. (2007). Optimal Monetary Policy in a Small Open Economy under Segmented Asset Markets and Sticky Prices. IMF Working paper 07, 217.

Mankiw, G. N. (2009). Macroeconomics. New York, USA: Worth Publishers Inc.

Merola, R. (2010). Optimal monetary policy in a small open economy with financial frictions. Deutsche Bundesbank, Discussion papers, 01/2010.

Mundell, R. A. (1963). Capital mobility and stabilization policy under fixed and flexible exchange rates. Canadian Journal of Economic and Political Science 29 (4): 475-485.

Parrado, E. (2004). Inflation Targeting and Exchange Rate Rules in an Open Economy. IMF Working Paper, WP/04/21. 